\title{
The Measurement Model of Professional Operation of State Administration
}

\author{
Milan Rman \\ Republic of Slovenia, Administrative Unit Trebnje, Slovenia \\ milan.rman@gov.si \\ https://orcid.org/0000-0002-7154-3921 \\ Marjan Brezovšek \\ University of Ljubljana, Faculty of Social Sciences, Slovenia \\ marjan.brezovsek@fdv.uni-lj.si \\ https://orcid.org/0000-0002-4106-0902 \\ Janez Stare \\ University of Ljubljana, Faculty of Public Administration, Slovenia \\ janez.stare@fu.uni-lj.si \\ https://orcid.org/0000-0002-1265-9430
}

Received: 22. 8. 2020

Accepted: 21. 9. 2020

\section{ABSTRACT}

This paper presents the study of a measurement model of professional operation of state administration. From the perspective of reliable performance of state functions, the professional operation of state administration represents one of the goals of social change. Based on theoretical-analytical findings, a measurement model of professional operation of state administration was designed. It consists of three dimensions, namely: reliability of state administration, professionalisation of the administrative profession, and competence of employees. The reliability dimension is represented by the element of legality and economic efficien$c y$, the profession dimension is based on power, autonomy, knowledge and responsibility, and the competence dimension includes elements of leadership and ethics. The measurement model was tested in the Slovenian state administration. The results of the research confirm the connection between the three aforementioned dimensions of professional operation of state administration and, consequently, the validity of the designed model.

Keywords: professional operation, state administration, reliability of state administration, administrative profession, competence, measurement model 


\section{Introduction}

State administration encounters the same problems in all types of democracies: how to provide competent, effective, legitimate, responsible, responsive, professional and just public service. The two great questions about state administration in democracy are thus connected with legitimacy and effectiveness, which also includes professionalism. Both questions are connected to the concept of reliable administration (Hood, 1991; Brezovšek 2000; Toonen, 2005). Administration without professional officers is not reliable. Administrative reliability is well grounded on the quality of administrative reign (Leftwich, 1993, p. 614) and ensures the legitimacy of the regime, its stability and credibility. Sarker (2019, pp. 1-5) in connection with professionalism (as a one of the core values of public (state) administration) expose accountability, transparency, coordination of works, implementing legislation, advocacy, responsiveness, competence and conduct, ethics and bureaucratic behaviour, law implementation, professional autonomy, ...

The purpose of the research was to discover the existence of connection and mutual dependence of dimensions of the theoretical model of professional operation of state administration with a goal of shaping the measurement model. A hypothesis was created on the basis of the presented problem: The professionalism of Slovenian state administration operation is determined by the level of its reliability, profession and leadership.

The article presents the theoretical framework of the model of professional operation of state administration, which is designed on the basis of analysis of the development of state administration and the development of various models of administration connected to it. The central point of the research was taken by the question which elements contribute to professionalisation of state administration. This was followed by the test of the model in practice by Slovenian state administration in the example of administrative units. Administrative units perform most tasks of administrative decision-making of the state on the first level of administrative decision-making, therefore they represent the most direct link between citizens and the state. It is that part of state administration, which (due to the field of implementing administrative services on the first level) is most usually exposed in relation to customers. On the basis of the results of the research the measurement model was designed and the hypothesis check-up was carried out.

\section{Model of professional state administration}

Professional operation of state administration as the social subsystem represents an important prerequisite for stability, development and competitiveness of the state. In addition, like other public sector organizations, they influence many dimensions of citizens' lives, they employ large numbers of people, spend taxpayers' money, cooperate with institutions from other countries and invest in different areas of the economy, society and the environment (Tomaževič, 2019, p. 1999). Considering the historical, incidence and 
interest complexity, it is practically impossible to unanimously and comprehensively explain the complexity of the area of state administration; however, there is one key question: what makes the state administration effective in the eyes of citizens and political, decision-making authorities. By shaping the model of professional operation of state administration we wish to answer this question in particular. At this point, analysis of findings from the areas of professional administration as reliable administration was made (classic and modern concept of reliable administration, analytical model of reliable administration), characteristics of official profession (also from the perspective of leading people, human resources management, competences and career system) and ethics of operation. The theoretical construct of the model of professional state administration, designed on this basis, consists of three dimensions: reliability, official profession and competences.

\subsection{Reliability}

There are two main goals of the state administration on the abstract level in the concept of reliable administration: (1) legitimacy, when citizens respect decisions of the state administration and (2) efficiency, when decisions need to provide adequate results. From the perspective of legitimacy, professional state administration is the one, the operation of which the citizens accept as valid and justified in terms of values and interests. Legitimacy includes the aspect of legality and political control, efficiency, professionalism and capability of managing the expenses (Brezovšek, 2000, pp. 255-256). The importance the rule of law for state administration activity means that the rule of law guarantees the legality of administrative decisions. Effectiveness of state administration operation is to a large extent connected with expedience and economic efficiency of the state administration. The emphasis is on greater financial discipline and cost-effectiveness of operation, which has a goal of lowering direct expenses, rising the effectiveness and limiting the operational costs (Hood, 1996, p. 271). To achieve expedience and economic efficiency of use of public resources (Cardona, 1999, pp. 8-14), which is carried out through budgetary financing, different forms of monitoring the budget have been established.

On this basis we placed the reliability dimension into the model (theoretical construct), which is determined by two elements: legality and economic efficiency.

\subsection{Profession}

Professions are constantly evolving, albeit at a slower or faster pace depending on sector environments in which they operate (Gregory, 2020, p. 641). Development of professionalisation of state administration is importantly connected with transition from providers in organisations, who perform public tasks of laymen, to professional workers in administration (Pusić, 1996, p. 61). There are different opinions about whether professionalisation of administration is representing processes, as regarded by the classic model of 
profession development. There are namely different viewpoints about official/administrative profession. Some say that justification of administration profession must originate from principles of democratic administration, while others express scepticism towards professionalisation of administration profession due to problems of clear definition of functions performed by state administration, and the third estimate that special administrative profession would be a threat to democratic administration and represent weakening of control of providers of administrative activities (McDonald III, 2010, p. 816). Public employees, as groups of professionals, they have been granted autonomies to regulate client and case treatment, to structure and strengthen knowledge and skills, and to improve assessment and action (Noordegraaf, 2016, p. 784).

Characteristics which mark professions are despite different treatments of processes of professionalisation (treatment of professionalisation through phases of development, Wilensky (1964) or treatment of certain characteristics, Leicht and Fennell (2001) remain similar. Knowledge, power and influence, autonomy, responsibility and ethics are exposed. While knowledge, responsibility and ethics can be treated as elements of old professionalism, in the context of social changes characteristics of power, influence and autonomy from the perspective of traditional professions in professionalisation of official profession mark its altered activity of new professionalism, when quality of service is in the foreground (Hargreaves, 1994, p. 437). Professionalism denote a bundle of HR practices that are generally considered in the normative literature as universal "good practices". Professionalism or professional identification is an important antecedent to public sector motivation (Battaglio and French, 2016, p. 129).

On this basis we placed the profession dimension into the model (theoretical construct), which is determined by four elements: power, autonomy, knowledge and responsibility.

\subsection{Competences}

Ability of professional operation of public employees is increasingly more often connected to the concept of competences. In the workplace, we use our competencies to perform a variety of behaviours and activities, which in turn generate outputs (products and services) that we provide to others (Stare and Klun, 2018, p. 82). Competences are a mix of motives, self-image, social roles, various skills, characteristics of an individual, which are used by the individual and lead to better activity at workplace (Boyatzis, 1982, p. 21). Competent people are those who can create valuable results without excessively costly behaviour (Gilbert, 1996, p. 17).

Concept of professional operation of state administration, considering reliability and profession, exposes particularly two elements of competence: leading people and ethical operation. Leading people is a multi-layered social phenomenon. Constant changes and influence on organisation (as a goal-oriented social system) in such way that it can carry out tasks are typical 
of it (Stare and Seljak, 2013, p. 38). Social and technological changes in the twentieth century developed new approaches also on the area of leadership. In contrast to classic approaches, new approaches have some common characteristics: (1) they emphasise emotional and symbolic behaviour of leaders, (2) they discover ways, how leaders achieve loyalty of followers, (3) they emphasise complexity of leading and the aspect of a common person of leading (Robbins, 1998, p. 327).

This part of professionalism (not just this part, but in particular this one) is also defined by the ethical dimension of operation. Ethical behaviour in state administration is a constant process of leadership, which includes the concept of personal integrity and with personal honesty of leader, who has, together with consistency in his statements, rewarding ethical behaviour, just behaviour towards employees, the greatest influence on ethical operation of its subordinates (Pečarič, 2008, pp. 254-255).

On this basis we placed the competence dimension into the model (theoretical construct), which is determined by two elements: ethics and leadership.

\section{Operationalisation of variables in the measurement model}

With the purpose of translation of the existence of connectivity of individual dimensions, a measurement model was shaped, which consists of 8 sets of elements. Each element was operationalised with descriptive variables (and labels, used in empirical testing (Table 1). 
Table 1: Operationalisation of variables

\begin{tabular}{|c|c|}
\hline 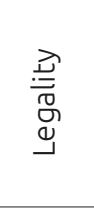 & $\begin{array}{l}\text { - The legal basis for the implementation of public tasks by officers is } \\
\text { accurately determined. (leg1) } \\
\text { - The content of legal relationships in material legislation between citi- } \\
\text { - } \quad \text { : }\end{array}$ \\
\hline 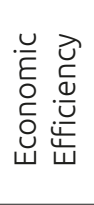 & $\begin{array}{l}\text { - Economic efficiency of operation of state administration is limited by } \\
\text { absence of marketing mechanisms of competitiveness. (eco1) } \\
\text { - Mechanisms of budgetary use encourage expenditure economy and } \\
\text { the economic efficiency of operation. (eco2) } \\
\text { - }\end{array}$ \\
\hline 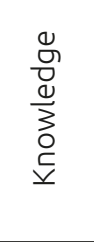 & $\begin{array}{l}\text { - The type of degree is important for working in the state administra- } \\
\text { - } \quad \text { Knon. (kno1) } \\
\text { ministration enables better quality of work with citizens and co-wor- } \\
\text { kers. (kno2) } \\
\text { - }\end{array}$ \\
\hline $\begin{array}{l}\text { ¿े } \\
\text { o } \\
0\end{array}$ & $\begin{array}{l}\text { - The officers influence the development of legal state. (pow1) } \\
\text { - The officers influence the implementation of principles of better } \\
\text { legislation (elimination of administrative obstacles, simplification of } \\
\text { legislation, preparation of new regulations). (pow2) } \\
\text { - }\end{array}$ \\
\hline 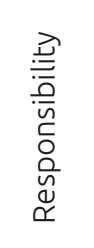 & $\begin{array}{l}\text { - State administration has established adequate forms of control of } \\
\text { officers' work. (res } 1 \text { ) } \\
\text { - State officers are responsible for the cooperation in the co-creation } \\
\text { of public policies and for contribution to regulations of better quali- } \\
\text { ty. (res2) } \\
\text { : }\end{array}$ \\
\hline 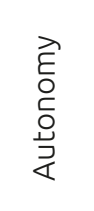 & $\begin{array}{l}\text { - Forming rules and legal requirements of officer's work are set by } \\
\text { elected representatives of the political authority. (aut } 1 \text { ) } \\
\text { - } \quad \text { Autonomy of officers' work is determined by the level of hierarchy in } \\
\text { the administrative system. (aut2) } \\
\text { - }\end{array}$ \\
\hline 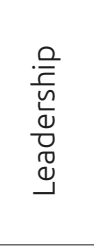 & $\begin{array}{l}\text { - Leading significantly influences the development of professionalisa- } \\
\text { tion of state administration. (lea1) } \\
\text { - Leading with introduction of entrepreneurial principles of success } \\
\text { and effectiveness is limited by values of administrative leading of } \\
\text { protection of general social benefits. (lea2) } \\
\text { : }\end{array}$ \\
\hline 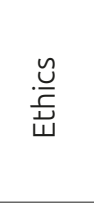 & $\begin{array}{l}\text { - When implementing public tasks, the officials act in accordance with } \\
\text { values, responsibility and principles of ethical treatment. (eth1) } \\
\text { - The officials know mottos and principles of obligatory ethical condu- } \\
\text { ct. (eth2) } \\
\text { - }\end{array}$ \\
\hline
\end{tabular}

Source: own 
The formed theoretical construct serves as the basis for identification of those key elements of state administration, which make it professional and for determining the existence of connection of individual elements.

\section{Research methods}

The research used quantitative method of research. In order to collect data, web questionnaire was used, which was structured and contained closed type questions. The measurement instrument consists of eight substantive sets with 39 statements. The respondents expressed their agreement with the statements on a five point Likert scale (1: "strongly disagree", 2: "disagree", 3: "neither agree nor disagree", 4: "agree", 5: "strongly agree". In the last, ninth part, the respondents answered five short questions of closed type, which refer to socio-demographic characteristics of respondents: their gender, age, years of service in public administration and private sector, and their course of study.

The data was collected through an online questionnaire ( $1 \mathrm{ka}$ web tool). The connection to the questionnaire was sent to 58 heads of administrative units in 2016. They were asked to solve the questionnaires and to forward the electronic message with the connection to the online survey to other officials at leading positions in their administrative unit. There were 229 officials on a position or leading work places in administrative units in Slovenia during the time of the research (MJU, 2016). The sample included $48.03 \%$ of the managerial structure of administrative units (AU). Actual state of persons of female gender in the leading structure of Slovenian $\mathrm{AU}$ is $73 \%$ and the sample included $69.1 \%$ of persons of female gender. Considering the responsiveness and the identification of gender structure of the sample it can be concluded that the sample represents in its important part the managerial structure of officials at the position in AU of Slovenia.

The sample has a little more than two thirds of persons of female gender (69.1\%) and nearly a third (30.9\%) of persons of male gender. The average age of a respondent is 51.56 years. The youngest respondent is 33 years old and the oldest is 64 years old. The "age" variable is quite normally distributed, while the distribution of the variable is somewhat asymmetric to the left and flattened. The smallest value of the "years of service in private sector" variable is 7 years, whereas the highest value is 39 years. On average, the respondents have 23.67 years of service in private sector. Also, the "years of service in private sector" variable is not normally distributed and the distribution of the variable is asymmetric to the right and pointed. The smallest value of the "years of service in private sector" variable is 0 years, whereas the highest value is 25 years. On average, the respondents have 3.55 years of service in private sector. The "years of service in private sector" variable is not normally distributed and the distribution of the variable is asymmetric to the right and pointed. Most respondents have legal education (42.4\%), education in administrative science (18.2\%) and the same part has economic education (18.2\%). There is a smaller degree of respondents with a degree in natural sciences $(9.1 \%)$, and the smallest one includes those who completed an organisational course of study (7.1\%), sociology (4.0\%) or other course of study (1.0\%). 
The collected data was processed in the statistics program IBM SPSS 23.0 and MS Excel, where univariate, bivariate and multivariate analyses were carried out. The structural equation modelling (hereinafter as: SEM) was carried out in program AMOS. The collected data was at first transferred into a database, where they were edited for further processing. To describe the examined phenomena, analysis of frequencies and descriptive analysis were used. Bivariate correlation analysis was carried out with the purpose of research of the link between the variables. To check the inter-connections between pairs of variables, Pearson's correlation coefficient was used.

In AMOS, confirmatory factor analysis was performed, where measurement model was created on the basis of findings from the bivariate correlation analysis and on the basis of content relevance of connections between constructs. Confirmatory factor analysis was carried out with measurement model in the context of structural equation modelling, in which manifest variables were included due to a small number of units in the sample, which were previously formed as averages of measured variables, which represent this construct. The adequacy of combining measured variables into newly formed variables, which represent constructs, was checked with confirmatory factor analysis, in the context of which we checked reliability and validity of combining measured variables into new ones.

In the SEM procedure, a measurement model was created, into which all new variables as averages of measured variables were placed, and then, in accordance with theoretically assumed conceptual model, latent variables were allocated to new variables. In this case we are talking about the measurement model, the purpose of which is performance of confirmatory factor analysis and validation of basic hypothesis of the research, that professionalism of state administration is determined by its reliability, competences of employees and their profession. In creating the measurement model we strived for creating such latent constructs, for which high values of weights at manifest variables which form these constructs would have been achieved, and at the same time towards high reliability and validity of formed constructs. The measurement model was formed on the basis of theoretically assumed links between constructs and its purpose was to check the hypothesis.

\section{The results of the research}

\subsection{The results of the research with the descriptive statistics of variables}

The basic descriptive statistics (Table 2) for variables with interval level of measurement or variables, which were considered as interval, include the numerus of responses, the smallest and the biggest value, the arithmetic mean (average value, AM) and the standard deviation (SD) from the arithmetic mean. The coefficient of skewness (CS) and coefficient of kurtosis (CK) are listed as indicators of normality of distribution. Normality of distribution was checked by Kolmogorov-Smirnov and Shapiro-Wilk test. 
Table 2: Basic descriptive statistics

\begin{tabular}{|c|c|c|c|c|c|c|c|}
\hline & $\mathrm{N}$ & $\min$ & $\max$ & AM & SD & CS & CK \\
\hline leg1 & 110 & 2 & 5 & 3.73 & 0.812 & -0.612 & 0.067 \\
\hline leg2 & 110 & 1 & 5 & 3.22 & 0.882 & -0.445 & -0.808 \\
\hline leg3 & 110 & 2 & 5 & 3.38 & 0.801 & -0.259 & -0.632 \\
\hline leg4 & 110 & 2 & 5 & 3.46 & 0.738 & -0.57 & -0.376 \\
\hline leg5 & 110 & 1 & 5 & 4.22 & 0.747 & -1.053 & 2.322 \\
\hline ekn1 & 110 & 1 & 5 & 3.21 & 0.959 & -0.051 & -0.76 \\
\hline ekn2 & 110 & 1 & 5 & 2.96 & 1.013 & 0.02 & -0.623 \\
\hline ekn3 & 110 & 1 & 5 & 3.28 & 0.92 & -0.522 & -0.198 \\
\hline ekn4 & 110 & 2 & 5 & 4.17 & 0.633 & -0.376 & 0.419 \\
\hline knl1 & 108 & 1 & 5 & 3.48 & 0.87 & -0.593 & 0.549 \\
\hline$k n l 2$ & 108 & 2 & 5 & 3.81 & 0.686 & -0.454 & 0.499 \\
\hline $\mathrm{knl3}$ & 108 & 1 & 5 & 3.14 & 0.87 & -0.275 & -0.387 \\
\hline knl4 & 108 & 1 & 5 & 4.06 & 0.74 & -1.092 & 2.776 \\
\hline knl5 & 108 & 1 & 5 & 4.37 & 0.731 & -1.585 & 4.363 \\
\hline pow1 & 108 & 1 & 5 & 3.28 & 0.905 & -0.274 & -0.163 \\
\hline pow2 & 108 & 1 & 5 & 3.23 & 0.781 & -0.313 & 0.219 \\
\hline pow3 & 108 & 1 & 5 & 3.50 & 0.837 & -0.876 & 0.913 \\
\hline pow4 & 108 & 1 & 5 & 2.93 & 0.839 & -0.245 & -0.279 \\
\hline pow5 & 108 & 1 & 5 & 3.64 & 0.932 & -0.627 & 0.106 \\
\hline res1 & 107 & 1 & 5 & 3.63 & 0.795 & -1.285 & 2.183 \\
\hline res2 & 107 & 1 & 5 & 3.46 & 0.883 & -0.541 & -0.399 \\
\hline res3 & 107 & 1 & 5 & 3.88 & 0.669 & -1.013 & 3.171 \\
\hline res4 & 107 & 1 & 5 & 3.56 & 0.815 & -0.946 & 0.903 \\
\hline res5 & 106 & 2 & 5 & 4.05 & 0.722 & -0.535 & 0.404 \\
\hline aut1 & 107 & 2 & 5 & 3.89 & 0.828 & -0.6 & 0.071 \\
\hline aut2 & 107 & 1 & 5 & 3.46 & 0.883 & -0.29 & -0.35 \\
\hline aut3 & 107 & 2 & 5 & 3.64 & 0.794 & -0.63 & -0.017 \\
\hline aut4 & 107 & 1 & 5 & 3.81 & 0.766 & -0.948 & 1.648 \\
\hline aut5 & 107 & 1 & 5 & 3.63 & 0.83 & -0.815 & 0.448 \\
\hline led1 & 102 & 1 & 5 & 4.1 & 0.622 & -1.328 & 6.351 \\
\hline led2 & 102 & 2 & 5 & 3.73 & 0.733 & -0.593 & 0.376 \\
\hline led3 & 102 & 2 & 5 & 3.69 & 0.689 & -0.794 & 0.656 \\
\hline led4 & 102 & 1 & 5 & 3.71 & 0.726 & -1.07 & 1.837 \\
\hline led5 & 102 & 1 & 5 & 3.56 & 0.683 & -1.072 & 1.362 \\
\hline eth1 & 102 & 2 & 5 & 4.07 & 0.55 & -0.323 & 1.925 \\
\hline eth2 & 101 & 2 & 5 & 4.1 & 0.592 & -0.615 & 2.355 \\
\hline eth3 & 102 & 1 & 5 & 3.54 & 0.897 & -0.791 & 0.578 \\
\hline eth4 & 102 & 2 & 5 & 4.35 & 0.639 & -0.703 & 0.634 \\
\hline eth5 & 102 & 1 & 5 & 3.21 & 0.871 & -0.233 & 0.006 \\
\hline
\end{tabular}

$\mathrm{N}$ - number of answers; min - lowest value; max - highest value; $\mathrm{AM}$ - arithmetic mean; SD - standard deviation; CS - coefficient of skewness; CK - coefficient of kurtosis 
Descriptive statistics of individual groups of variables show relatively low values of standard deviations. The majority of values of coefficients of skewness and kurtosis is situated within the interval $[-2,2]$, which means that distribution of variables does not significantly deviate from the normal one. A significant deviation from normal distribution has been detected only for the variables "leg5", "knl4", "knl5", "res1", "res3", "led1" (largest deviation) and "eth2".

In the context of "legality" the greatest degree of agreement (4.22) between respondents exists for the statement that the legitimacy of state administration is strengthened with its openness and transparency ("leg5"), and the smallest degree of agreement (3.22) for the statement that the content of legal relations in material legislation between the citizens and the state is stable and predictable ("leg2"). In the context of "economic efficiency" the greatest degree of agreement between the respondents (4.17) is about the statement that principles of economy, effectiveness and cost efficiency are important for work of the state body ("ekn4"), whereas the smallest degree of agreement (2.96) exists about the statement that mechanisms of budgetary use encourage cost efficiency and economic efficiency of business activities ("ekn2"). Generally, the greatest degree of agreement by respondents (4.17) is about the fact that officers' knowledge enables professional competence and independence in the process of decision-making ("knl5"), namely in the context of "knowledge". The smallest degree of agreement in this context (3.24) is about the fact that the state administration enables its officers target training and upskilling ("kn(3"). However, disagreement with this statement remains quite high.

In the context of "power/influence" the greatest agreement among the respondents (3.64) exists about the fact that the public attaches greater influence to the officers for their regulation of social relations, than they actually have regarding their competencies ("pow5"). Significant agreement (3.5) among the respondents exists also about the fact that state administration contributes to competitive ability of the economy by the implementation of acquis ("pow3"). The smallest degree of agreement in this context and also in the entire research is about that the fact that the public appreciates and trusts the officers about their implementation of public tasks ("pow4").

In the context of "responsibility" among respondents, the highest degree of agreement (4.05) exists about the fact that the officer is responsible for serving the citizens and to solve their problems in legal administrative relations ("odg5"), whereas the lowest degree of agreement (3.46) occurs for the fact that state officers are responsible for co-creation of public policies and for contribution to regulative of better quality ("odg2"). In the context of "autonomy" the highest degree of disagreement among respondents (3.89) exists about the fact that forming rules and legal requirements of officer's work are determined by elected representative of political authority ("aut1"), and the lowest degree of agreement (3.46) about the autonomy of officers' work being determined by the level of hierarchy in the administrative system ("aut2"), but the agreement about this statement remains quite high. However, the 
differences in respondents' agreements about individual factors in this context are very small (only 0.43 ).

In the context of "leadership", the greatest degree of agreement (4.1) among the respondents exists about the fact that leading significantly influences the development of professionalisation of state administration ("lea1"), and the smallest, but still quite high (3.56) about the fact that leading transforms from hierarchical individual paradigms into co-operative network activities ("lea5"). In the context of "ethics", the greatest degree of agreement (4.35) among the respondents is about the fact that the awareness of ethical responsibility and obligation is a human virtue, which cannot be reduced to regulated ethical conduct ("eth4"). The smallest degree of agreement (3.21) among the respondents, both in the entire research and in the context of "ethics", exists in the fact that an effective mechanism of control and responsibility has been established for the compliance of ethical practices of officers.

\subsection{Analysis of validity and reliability}

Because we want to perform further analyses on full data matrix, we check the pattern of repetition of missing values by Little MCAR test. The level of statistical characteristic $x^{2}\left(x^{2}=128.8 ; d f=133 ; p=0.586\right)$ shows that the missing values for variables, which were measured on a five point Likert scale of agreement, are missing completely randomly $(p>0,05)$. Considering the fact that the percentage of missing values for individual variables are moving within $0 \%$ and up to $8 \%$, and considering the previous finding that the missing values are completely randomly missing, values with EM (expectation-maximisation) algorithm are entered in the existing data matrix. All further analyses are made on full data matrix.

In the context of validity of the construct, which is related to the adequacy of measuring the phenomenon, we check the convergent validity. Convergent validity determines the level of connectedness of several variables, for which we assume that they measure the same construct. High connectedness shows actual measuring of the same construct. AVE values which are higher than 0.5 suggest the convergent validity of constructs. The reliability of measurements was checked from the perspective of internal consistency of measurement (Cronbach's alpha coefficient). For each individual construct (factor) confirmatory factor analysis was made in AMOS with the purpose to check the validity and the reliability of constructs. We used: AVE as the indicator of convergent validity, CR for composite reliability, Cronbach's a for internal consistency of the construct. Measurement models were simplified in the process of confirmatory factor analysis of modified in a way that certain fit was achieved. Thus, they were after the process of removing variables, which had low weight values or standardised regression coefficients. Variables, which were preserved in the analysis, are presented in Table 3. 
Table 3: Indicators of validity and reliability of constructs in the mode

\begin{tabular}{|c|c|c|c|c|c|c|}
\hline & & & $\lambda$ & $\mathrm{CR}$ & AVE & Cronbach's a \\
\hline leg1 & $\leftarrow$ & \multirow{3}{*}{ legality (e1) } & 0.636 & \multirow{3}{*}{0.819} & \multirow{3}{*}{0.483} & \multirow{3}{*}{0.725} \\
\hline $\operatorname{leg} 2$ & $\leftarrow$ & & 0.837 & & & \\
\hline $\operatorname{leg} 3$ & $\leftarrow$ & & 0.587 & & & \\
\hline ecn2 & $\leftarrow$ & \multirow{2}{*}{$\begin{array}{c}\text { economic } \\
\text { efficiency (e2) }\end{array}$} & 0.727 & \multirow{2}{*}{0.832} & \multirow{2}{*}{0.585} & \multirow{2}{*}{0.734} \\
\hline ecn3 & $\leftarrow$ & & 0.801 & & & \\
\hline $\mathrm{klg} 4$ & $\leftarrow$ & \multirow{2}{*}{ knowledge (e3) } & 0.721 & \multirow{2}{*}{0.793} & \multirow{2}{*}{0.526} & \multirow{2}{*}{0.689} \\
\hline klg5 & $\leftarrow$ & & 0.729 & & & \\
\hline pow1 & $\leftarrow$ & \multirow{3}{*}{ power (e4) } & 0.771 & \multirow{3}{*}{0.827} & \multirow{3}{*}{0.493} & \multirow{3}{*}{0.733} \\
\hline pow2 & $\leftarrow$ & & 0.756 & & & \\
\hline pow3 & $\leftarrow$ & & 0.560 & & & \\
\hline rsy1 & $\leftarrow$ & \multirow{3}{*}{ responsibility (e5) } & 0.517 & \multirow{3}{*}{0.746} & \multirow{3}{*}{0.404} & \multirow{3}{*}{0.633} \\
\hline rsy2 & $\leftarrow$ & & 0.842 & & & \\
\hline rsy3 & $\leftarrow$ & & 0.484 & & & \\
\hline $\operatorname{atn} 2$ & $\leftarrow$ & \multirow{3}{*}{ autonomy (e6) } & 0.416 & \multirow{3}{*}{0.71} & \multirow{3}{*}{0.406} & \multirow{3}{*}{0.571} \\
\hline $\operatorname{atn} 3$ & $\leftarrow$ & & 0.389 & & & \\
\hline atn5 & $\leftarrow$ & & 0.945 & & & \\
\hline Isp1 & $\leftarrow$ & \multirow{4}{*}{ leadership (e7) } & 0.548 & \multirow{4}{*}{0.832} & \multirow{4}{*}{0.432} & \multirow{4}{*}{0.749} \\
\hline Isp3 & $\leftarrow$ & & 0.723 & & & \\
\hline Isp4 & $\leftarrow$ & & 0.691 & & & \\
\hline $\operatorname{lsp} 5$ & $\leftarrow$ & & 0.654 & & & \\
\hline eth1 & $\leftarrow$ & \multirow{4}{*}{ ethics (e8) } & 0.839 & \multirow{4}{*}{0.863} & \multirow{4}{*}{0.496} & \multirow{4}{*}{0.771} \\
\hline eth2 & $\leftarrow$ & & 0.782 & & & \\
\hline eth3 & $\leftarrow$ & & 0.588 & & & \\
\hline eth5 & $\leftarrow$ & & 0.569 & & & \\
\hline
\end{tabular}

Source: own

As is evident from Table 3, the CR values for all constructs are exceeding the limit values of 0.6 , so the constructs achieve high composite reliability. The values of the average of extracted variances AVE, which refer to convergent validity of constructs, are approaching the limit values $(0,5)$ or exceed them for most of the constructs. However, we estimate that AVE values for con- 
structs, which are less than 0.5 , are not critically low. When evaluating internal consistency of constructs with Cronbach's a coefficient, it shows reliability of constructs, by which an exception is only the "autonomy" construct, however on the other side of composite reliability is relatively high

\subsection{Descriptive statistics of variables in a model}

From variables, indicated in Table 3, we created new variables as the averages of all retained variables. Therefore, a presentation of descriptive characteristics of newly created variables in the model (Table 4) follows, with which detailed insight into the studied problem is enabled. At the same time, the purpose of this presentation is the display of basic characteristics of variables, on which further analyses are based (analysis of correlations and structural equation modelling), with which we answer the raised research question and check the hypothesis.

In the context of descriptive analysis we are interested into smallest and largest values, the arithmetic mean and the standard deviation. The kurtosis and the skewness of distribution of variables was also checked. The normality of distribution of variables was identified with Kolmogorov Smirnov test with Lilliefors correction and Shapiro-Wilk test. Descriptive statistics of new variables show relatively low values of standard deviations, since they are smaller than one (Table 4). For all formed variables, values of coefficients of skewness are negative, so the distributions are asymmetric to the left. Values of coefficients of kurtosis are negative in formed "legality" and "economic efficiency" variables, which means the distribution of variables is flat. For other variables, values of coefficients of kurtosis are positive, which shows the pointed distribution of variables. The majority of values of coefficients of skewness and kurtosis is situated within the interval $[-2,2]$, which means that distribution of variables is acceptably asymmetric and flattened or pointed.

Table 4: Descriptive statistics of formed variables

\begin{tabular}{|l|c|c|c|c|c|c|c|}
\hline & $\mathrm{N}$ & $\mathrm{min}$ & $\mathrm{max}$ & $\mathrm{AM}$ & $\mathrm{SD}$ & $\mathrm{CS}$ & $\mathrm{CK}$ \\
\hline legality (e1) & 110 & 2 & 5 & 3.44 & 0.668 & -0.302 & -0.283 \\
\hline economic efficiency (e2) & 110 & 1 & 5 & 3.12 & 0.86 & -0.213 & -0.223 \\
\hline knowledge (e3) & 110 & 2 & 5 & 4.22 & 0.636 & -0.985 & 2.186 \\
\hline power (e4) & 110 & 1 & 5 & 3.34 & 0.675 & -0.669 & 2.005 \\
\hline responsibility (e5) & 110 & 1 & 5 & 3.65 & 0.591 & -0.8 & 1.988 \\
\hline autonomy (e6) & 110 & 2 & 5 & 3.57 & 0.607 & -0.323 & 0.046 \\
\hline leadership (e7) & 110 & 2 & 5 & 3.75 & 0.498 & -1.309 & 3.905 \\
\hline ethics (e8) & 110 & 2 & 5 & 3.71 & 0.562 & -0.182 & 1.482 \\
\hline
\end{tabular}

Source: own 
In the context of formed variables the highest average values for the "knowledge" variable imply that for the respondents, knowledge is the most important ingredient for professional state administration, whereas the lowest degree of agreement among the respondents was sensed in the area of economic efficiency of state administration.

The test of normality of distribution of formed variables, which was carried out with Kolmogorov-Smirnov and Shapiro-Wilk test is shown in Table 5. All values of statistics are statistically characteristic on level $p<0.01$, which shows statistically typical deviation of distribution of these variables from the normal one.

Table 5: Normality of new variable distribution

\begin{tabular}{|l|c|c|c|c|c|c|}
\hline & \multicolumn{3}{|c|}{ Kolmogorov-Smirnov } & \multicolumn{3}{c|}{ Shapiro-Wilk } \\
\hline & Statistics & $\mathrm{df}$ & $\mathrm{P}$ & Statistics & $\mathrm{df}$ & $\mathrm{P}$ \\
\hline legality (e1) & 0.177 & 110 & 0.000 & 0.954 & 110 & 0.001 \\
\hline economic efficiency (e2) & 0.128 & 110 & 0.000 & 0.956 & 110 & 0.001 \\
\hline knowledge (e3) & 0.202 & 110 & 0.000 & 0.877 & 110 & 0.000 \\
\hline power (e4) & 0.154 & 110 & 0.000 & 0.929 & 110 & 0.000 \\
\hline responsibility (e5) & 0.155 & 110 & 0.000 & 0.932 & 110 & 0.000 \\
\hline autonomy (e6) & 0.175 & 110 & 0.000 & 0.949 & 110 & 0.000 \\
\hline leadership (e7) & 0.163 & 110 & 0.000 & 0.904 & 110 & 0.000 \\
\hline ethics (e8) & 0.112 & 110 & 0.002 & 0.956 & 110 & 0.001 \\
\hline
\end{tabular}

Source: own

The analysis of correlations was carried out with the purpose of checking interconnections between the variables (Pearson's correlation coefficient). As set out in correlation matrix of generated variables (table 6), there are statistically characteristic connections among almost all variables (except in case of the autonomy and legality pair of variables and the autonomy and power pair of variables). It has been discovered that there are moderate, medium positive connections between the following pairs of variables power and economic efficiency ( $r=0.541)$, responsibility and economic efficiency $(r=0.527)$, responsibility and knowledge $(r=0.477)$, responsibility and power $(r=0.596)$, leadership and knowledge $(r=0.435)$, leadership and power $(r=0.505)$, leadership and responsibility ( $r=0.586)$, ethics and knowledge ( $r=0.442)$, ethics and responsibility $(r=0.541)$ and ethics and leadership $(r=0.513)$. 
Table 6: Correlation matrix of generated variables

\begin{tabular}{|c|c|c|c|c|c|c|c|}
\hline & legality & $\begin{array}{l}\text { economic } \\
\text { efficiency }\end{array}$ & knowledge & power & responsibility & autonomy & leadership \\
\hline \multicolumn{8}{|l|}{ legality } \\
\hline $\begin{array}{l}\text { economic } \\
\text { efficiency }\end{array}$ & $0.397^{* *}$ & & & & & & \\
\hline knowledge & $0.221^{*}$ & $0.218^{*}$ & & & & & \\
\hline power & $0.336^{* *}$ & $0.541^{* *}$ & $0.291^{* *}$ & & & & \\
\hline responsibility & $0.306^{* *}$ & $0.527^{\star *}$ & $0.477^{* *}$ & $0.596^{* *}$ & & & \\
\hline autonomy & 0.159 & $0.220^{*}$ & $0.276^{* *}$ & 0.169 & $0.233^{*}$ & & \\
\hline leadership & $0.257^{* *}$ & $0.386^{* *}$ & $0.435^{* *}$ & $0.505^{* *}$ & $0.586^{* *}$ & $0.314^{* *}$ & \\
\hline ethics & $0.382^{* *}$ & $0.394^{* *}$ & $0.442^{* *}$ & $0.342^{* *}$ & $0.541^{* *}$ & $0.330^{* *}$ & $0.513^{* *}$ \\
\hline
\end{tabular}

* - the connection is statistically typical on level $p<0.05$

* - the connection is statistically typical on level $p<0.01$

Source: own

The two variables, which form the latent variable "profession", i.e. "power" and "autonomy", are not statistically interconnected, and are at the same time statistically distinctly and strongly correlated with the remaining variables, which are distributed to other latent variables. Between the "legality" and "economic efficiency" variables, which form the latent variable "reliability" there is no visible prominent strong connection, by which the "economic efficiency" variable strongly correlates with some other variables, too. These findings are important for forming the measurement model in the SEM context.

\subsection{Confirmatory factor analysis}

In the context of confirmatory factor analysis (carried out in AMOS) we formed a measurement model, with which we are answering the set out hypotheses. Standardised regional weights (table 7 ) are higher than 0.5 for the majority of generated variables, except for the "autonomy" variable. The latter does not represent "profession" to such an extent as was intended at first. Through the analysis we have discovered that "knowledge" and "responsibility" as the ingredients of the professional state administration, should most appropriately be considered as a part of the "profession" construct in addition to "power" and "autonomy", as well as "ethics" as a part of the "competences" construct, together with "leadership". 
Table 7: Standardised regression weights of variables in the measurement model

\begin{tabular}{|c|c|c|}
\hline & & $\lambda$ \\
\hline legality (e1) & \multirow[b]{2}{*}{ reliability } & 0.511 \\
\hline $\begin{array}{l}\text { economic efficiency } \\
\text { (e2) }\end{array}$ & & 0.777 \\
\hline knowledge (e3) & \multirow{4}{*}{ profession } & 0.543 \\
\hline power (e4) & & 0.688 \\
\hline responsibility (e5) & & 0.882 \\
\hline autonomy (e6) & & 0.357 \\
\hline leadership (e7) & \multirow{2}{*}{ competences } & 0.755 \\
\hline ethics (e8) & & 0.679 \\
\hline
\end{tabular}

Source: own

It was discovered that we can confirm with high likelihood the existence of measurement model of professional state administration (Figure 1). By that it was found out that reliability, profession and competences are strongly connected and empirically proven ingredients of the model of professional state and are therefore an indispensable part of the model of professional state administration.

Figure 1: Connection of dimensions of professional state administration

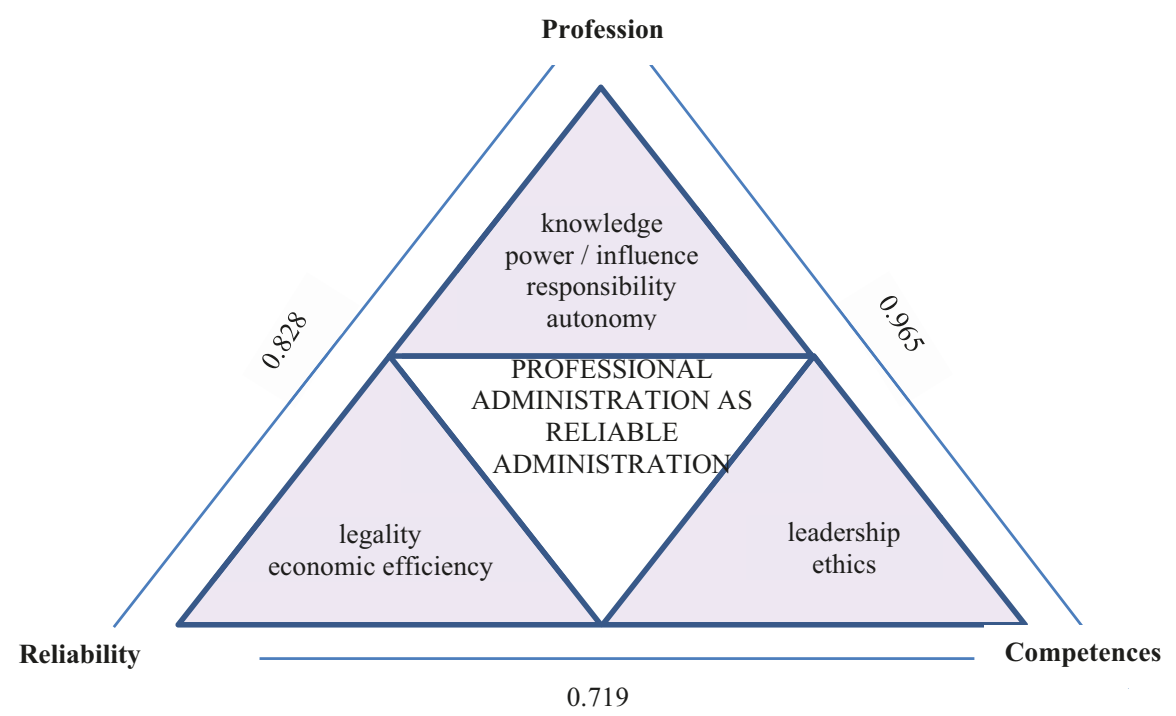

Source: own 
On the basis of connection of dimensions of professional administration, defined by eight elements of substantive sets of variables, which were formed on the basis of theoretical work we can confirm the theoretical approach with an empirical result (Table 7).

\section{Discussion}

On the basis of descriptive approach, a theoretically analytical model of professional administration was created, which was checked in the research. From a total of 44 statements we formed eight elements of substantive sets and then, on the basis of executed confirmatory analysis, created the latent variables in accordance with theoretical findings in order to check the presumed conceptual model of professional administration. On the analytical model we discovered high values of connectivity of manifest variables with latent variables, as well as high values of interconnectedness of latent variables (Figure 2). Thus, with empirical evidence, we were able to confirm the main hypothesis that professionalism of Slovenian state administration is determined by the level of its reliability, profession and competency.

Figure 2: Connectedness of latent and manifest variables in the measurement model of professional operation of state administration

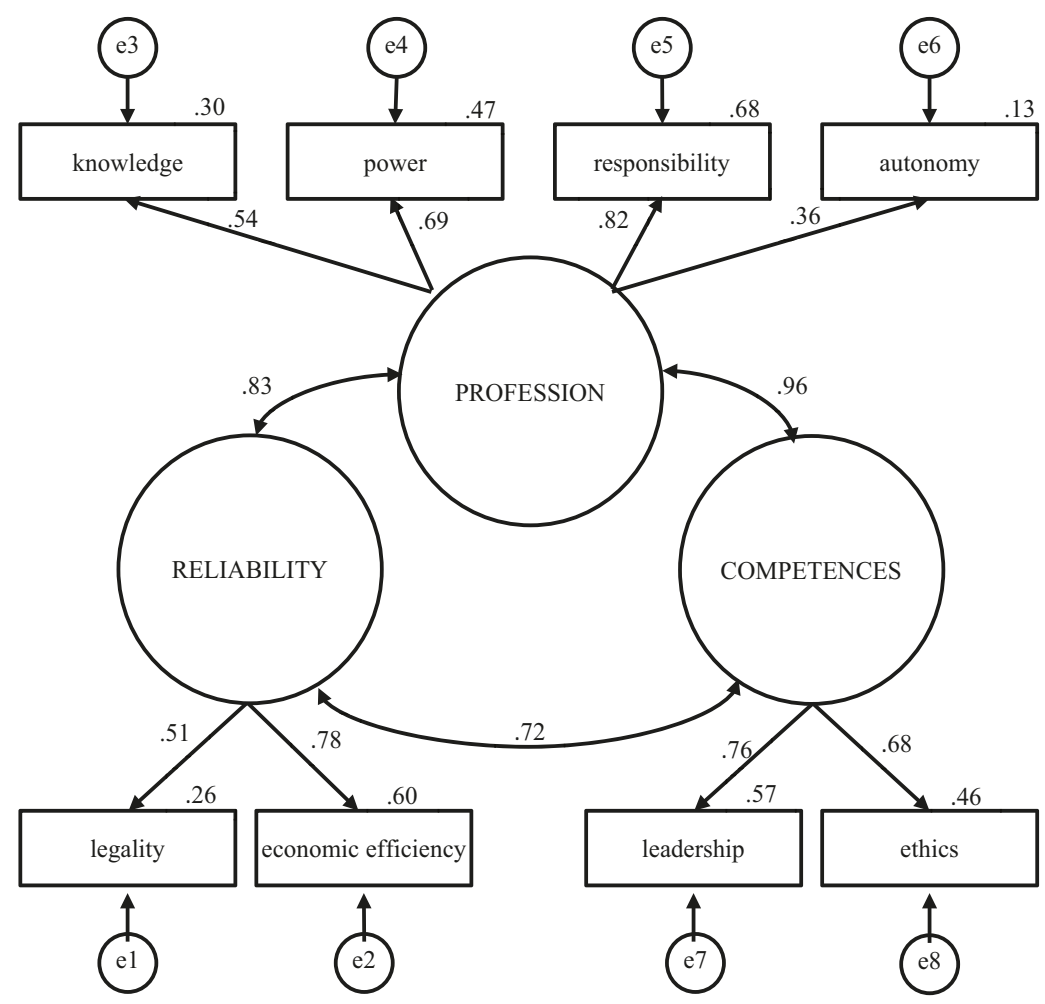

Source: own 
The differences between the highest and the lowest degrees of agreement with descriptive variables were found out to be in the interval between 0.2 1.2. The highest difference in agreeing has been observed for the variable of legality of professional administration; the respondents do not statistically importantly agree with the statement that legal bases for solving public tasks of officials are precisely specified. Nicolescu-Waggonner (2016) says, in connection with defined legal bases for the implementation of public tasks, that without Rule of Law democracy basically does not exist, by which he particularly exposes conflicts of interest and corruption (which is sensibly exposed by the presented model). Dragu and Polborn (2013, p. 1038) additionally expose the meaning of adequate legal bases, because they think that the rule of men necessarily undergirds the rule of law since legal limits invariably rest upon the government's willingness to respect them. Professional operation of state administration is basically and inseparably integrated in the performance of regulative reforms, which are part of a comprehensive reform of the public sector. Professional state administration carries out quality regulation, by which the findings of the research point out the needs for better regulations. The state is becoming regulatory (Majone, 1997, p. 143) and quality regulation means professional activity of state administration.

For the economic efficiency variable respondents with low degree of agreement perceive absence of mechanisms of encouragement of cost-effectiveness and economics of the budgetary use. The meaning of (clearly) defined mechanisms of encouraging cost effectiveness and economic effectiveness of budgetary use is expressed in various areas and levels of public sector (Glassman and Silverman, 2016; NCSL, 2011; Posner, Kue Ryu and Tkachenko, 2009). Despite the fact that economic efficiency and target financing was one of the fundamental requests of the transition of the administrative system, the results of the research show the absence of necessary mechanisms. The detected marks can be seen as the impulse for changes, necessary for providing legality and with it professional operation of state administration.

In the profession dimension, respondents express the lowest level of agreement with descriptive value "knowledge", where target training and upskilling are not set. Working environment of public officers is constantly changing and requests for continuous and target training and upskilling are included in strategies of education, trainings and upskilling, which Slovenia accepts for individual periods. "Constant" incentives helped towards that, which come to the state administration for years from "external institutions". (OECD, 1997). In the same manner, the document Public administration 2020 - strategy of development of public administration 2015-2020 recognises targeted training as one of the key goals of human resources policy for improvement of professional operation of state administration (MJU, 2015). Professionalism is enabled by adequate professional competency, which provides adaptation, improvement, support, mobility, flexibility, management skills by officials (OECD, 1997).

The power/influence of the variable express the opinion that the public does not trust the officials with their implementation of public tasks. Trust is irrec- 
oncilably connected with operation of democracy (Almond and Verba, 1963) and the citizens do not explain the acts of the administration and its officers in empty space (Peters, 2001, p. 34). The operations of the management board is strongly embedded into the social environment, with which it also shares an inseparable level of trust. A professional state administration will also enjoy the trust of its nationals.

Regarding the responsibility variable, respondents do not feel responsible for the cooperation in the formation of public policies and for contributing to a quality regulation. Results of the research warn on the problematic viewpoint of professional functioning of officers who do not feel bound to the participation in the formation of public policies, which is a core point of transfer from classic to modern management. The formation of policies assumes the combination of policy actors (Bevir, 2007). State administrations is obligated form regulations if these deviate from the social reality and are not in accordance with democracy. Based on the impact which public employees have on the government performance (Ingraham and Rubaii-Barrett, 2018; Perry, Mesch and Paarlberg 2006), an awareness needs to be established between them regarding their potential and actual impact on the formation of public policies.

Lowly estimated claim that autonomy of officers' work is determined by the level of hierarchy in the administrative system is a positive finding in terms of content. It confirms the finding that hierarchical structure of bureaucratic organisation does not limit professional and procedural independence of officers' work, which shows positive nature of leading competency, which is also based on trust and professionality. The results of the research in recognition of knowledge of independent officers' work, which is becoming autonomous, despite hierarchic organisational structure, confirm the findings (Pečarič, 2008, p. 243) that increasingly larger knowledge of employees and the complexity of their work lowers the needs of formal control, strict organisational structures and hierarchical commands, whereas ethics, values, trust and professionalisation are becoming more important.

In the dimension of competence, we have discovered the lowest estimate of agreement in descriptive variable that leading transforms from hierarchical individual paradigm into a co-operating network action. The results of the research completely confirm the findings that despite the fact that participation is being accepted as one of the fundamental social values, it does not mean that it would actually come to life in practice of state and other debates. There is also low estimate of agreement upon the fact that an effective mechanism of control and responsibility has been established for the compliance of ethical practices of officers. Warnings about ethical monitoring are related to wider issue of ethics in state administration (Georgescu, 2013; Raile, 2013; Tomescu and Popescu, 2013). In the research high values of awareness of the meaning of ethics for professional operation of state administration are confirmed, but the lack of effective mechanism of control and responsibility is critically exposed. Professional state administration is ethical only if it has adequate mechanisms of control and responsibility as well. 
The highest average values of formed variables are ranging in the interval of 3.12-4.22 (Table 4), while it is important to warn about low values in the contribution of presented variables, which are ranging in the interval of 2.96-3.89 and in the model of professional state administration expose the so-called grey areas of professional operation with challenges and improvements in the area of quality of regulation, budgetary effectiveness, targeted training, mechanisms of ethical control and responsibility, trust in state administration, etc.

Despite using the measurement analytical model to confirm the high level of the model of professional operation of state administration, a warning about an important deficit needs to be exposed for all three dimensions, since it can potentially perceptionally threat the further development of professionalisation of Slovenian state administration. The latter can only develop its operation if (1) in material legislation larger stability and predictability of legal relations between the citizens and the state will be established, (2) if the state officers will recognise the important aspect of their responsibility, represented by co-operation in co-creation of public policies and their contribution to regulations of better quality and (3) if leading will be able to transform, also on the basis of expected competent model, from the prevailing individual paradigm to collaborating network operation, which is assumed by the concept of new public leadership and serving the citizens.

\section{Conclusion}

The article discusses the model of professional operation of state administration. On the basis of the research we can confirm the existence of such model. The check of the latent variable "reliability", which represents one of the three constructs of the measurement model of professional administration operation shows that the respondents confirmed high values of agreement with variables, which describe the existence of an adequate systematic legislative framework for the operation of reliable administration. Likewise, the results confirm the existence of the legislative framework for cost stance for reliable operation, since the principles of economy, effectiveness and cost efficiency are recognised as the most important for the work of a state body.

For the second latent variable of the measurement model of "official profession" power/influence and autonomy should be particularly exposed (in addition to knowledge and responsibility), which are also included in the model as indicators of the existence of profession, which is establishing reliable administration. By checking the answers for the power/influence variable, the highest value was achieved by the statement that the public attaches greater influence to the officers for their regulation of social relations, than they actually have regarding their competencies, while at the same time the results have discovered the power/influence of the state administration, which contributes to the competitive qualification of the economy by implementation of acquis. The answers appear to contradict each other, but are indicative, since they on one hand warn about not clear enough understanding of the relationship between the politics and the administration in the public, as well 
as about the problem of own understanding of the position and the responsibility that the state administration has in shaping public policies and thus positive politicisation of its activity. The results of the estimated value of the variable autonomy are the highest in agreeing with the statement that forming rules and legal requirements of officer's work are set by decisions of elected representatives of the political authority. On the system level this finding shows low level of autonomy of official profession and opens the question of dichotomy between the politics and the administration and addresses the issue of the state of reliability.

The third latent variable "competence" is treated from the aspect of elements of leading and ethics. By confirming the carried out hypothesis, the elements of leading and ethics are shown as the most problematic variables. The greatest divergence is between the value of agreement in principle about the meaning of variables for the operation of reliable administration and perception about actual state in state administration operation.

From the measurement model of professional administration it can be concluded that the greater the degree of professionalism of the state administration, the greater the degree for which it will get recognised as reliable and competent, or the greater the degree of competency, the greater the professionalism or reliability of the state administration, or the greater the degree of reliability, the greater the degree of being recognised as professional and competent. Competences, profession and reliability are therefore necessary ingredients for state administration, when thought of as professional administration. 


\section{References}

Almond, A. G. and Verba, S. (1963). The civic culture: Political Attitudes and Democracy in Five Nations. SAGE Publications, Boston.

Battaglio, R. P. and French, P. E. (2016). Public Service Motivation, Public Management Reform, and Organizational Socialization: Testing the Effects of Employment At-Will and Agency on PSM among Municipal Employees. Public Personnel Management, 45(2) pp. 123-147.

Bevir, M. (2007). Public governance. London, Thousand Oaks.

Boyatzis, R. E. (1982). The competent manager: A model for effective performance. Wiley: New York.

Brezovšek, M. (2000). Kako do zanesljive uprave. Teorija in praksa, 37(2), pp. 264-278.

Cardona, F. (1999). Elements of the public administration integrity system in EU member states. SIGMA / OECD.

Dragu, T. and Polborn, M. (2013). The Administrative Foundation of the Rule of Law. The Journal of Politics, 75(4), pp. 1038-1050.

Georgescu, C. M. (2013). Qualitative Analysis on the Institutionalisation of the Ethics and Integrity Standard within the Romanian Public Administration. Revista de Științe Politice. Revue des Sciences Politiques, 37, pp. 320-326.

Gilbert, T. F. (1996). Human Competence. Silver Spring, MD: International Society for Performance Improvement.

Glassman, A. and Silverman, R. (2016). How to Get Cost-Effectiveness Analysis Right? The Case of Vaccine Economics in Latin America. Value in Health, 19(8), pp. 913-920.

Gregory, A. (2020). Chartered status and public relations' struggle for legitimacy. Corporate Communications: An International Journal, 25(4), pp. 639-653.

Hargreaves, D. (1994). The new professionalism: the synthesis of professional and institutional development. Teaching and Teacher Education, 10(4), pp. 423-438.

Hood, C. (1991). A Public Management for All Seasons? Public Administration, 69(spring), pp. 3-19.

Hood, C. (1996). Exploring variations in public management reform of the 1980. In H. Bakke, J. Perry and T. Toonen, eds., Civil Service Systems in Comparative perspective. Bloomington and Indianapolis: Indiana University Press, pp. 268-317.

Ingraham, P. W. and Rubaii-Barrett, N. (2018). Human resource management as a core dimension of public administration. Foundations of Public Administration Series. At <http://Faculty.cbpp.uaa.alaska.edu/afgjp/ PADM601\%20Fall\%202009/FPA-HRMArticle.pdf>, accessed 12 July 2018.

Leftwich, A. (1993). Governance, Democracy and Development in the Third World. Third World Quarterly, 14(3), pp. 605-624.

Leicht K. T. and Fennell, M., L. (2001). Professional Work: A Sociological Approach. Wiley-Blackwell.

Majone, G. (1997). From the Positive to the Regulatory State: Causes and Consequences of Changes in the Mode of Governance. Journal of Public Policy, 17(2), pp. 139-167. 
McDonald III and Bruce, D. (2010). The Bureau of municipal research and the development of professional public service. Administration and Society, 42(7), pp. 815-835.

Ministrstvo za javno upravo [MJU]. (2015). Javna uprava 2020, Strategija razvoja javne uprave 2015-2020. Ministrstvo za javno upravo.

Ministrstvo za javno upravo [MJU]. (2016). Data from the official website of the Ministry of public management, e-portal UE Slovenia.

NCSL. (2011). Health Cost Containment and Efficiencies NCSL. Briefs for State Legislators.

Nicolescu-Waggonner, C. (2016). No Rule of Law, No Democracy: Conflicts of Interest, Corruption, and Elections as Democratic Deficits. Albany, SUNY Press.

Noordegraaf, M. (2016). Reconfiguring Professional Work: Changing Forms of Professionalism in Public Services. Administration and Society, 48(7), 783-810.

OECD. (1997). Public Service Training in OECD Countries. SIGMA Papers, No. 16. Paris: OECD Publishing.

Pečarič, M. (2008). Uradništvo med formalnim in neformalnim vplivom na politiko in državljane. Ljubljana, Uradni list RS.

Perry, J., Mesch, D. and Paarlberg, L. (2006). Motivating employees in a new governance era: the performance paradigm revisited. Public Administration Review, 66(4), pp. 505-514.

Peters, B. G. (2001). The politics of bureaucracy (5th edition). London, New York: Routledge.

Posner, P., Kue Ryu, S. and Tkachenko, A. (2009). Public-Private Partnerships: The Relevance of Budgeting. OECD Journal on Budgeting.

Pusić, E. (1996). Nauka o upravi. Zagreb: Pravni fakultet.

Raile, E. D. (2013). Building Ethical Capital: Perceptions of Ethical Climate in the Public Sector. Public Administration Review, 73(2), pp. 253-262.

Robbins, S. (1998). Organisational Behavior: Concepts, Controversies and Applications. Upper Saddle River, New Jersey: Prentice-Hall International.

Sigma. (1999). European Principles for Public Administration. Sigma Paper, No. 27. Sigma, Paris. At <http://unpan1.un.org/intradoc/groups/public/ documents/nispacee/unpan006804.pdf> , accessed 2 February 2013.

Sarker, M.N.I. (2019). Public Administration as a Professional Practice. In Farazmand, ed., Global Encyclopedia of Public Administration, Public Policy, and Governance. At <https://link.springer.com/ referenceworkentry/10.1007\%2F978-3-319-31816-5_3853-1\#howtocites, accesed 1 June 2020.

Stare, J. and Klun, M. (2018). Required competencies in public administration study programs. Transylvanian Review of Administrative Sciences, 55 E, pp. 80-97.

Stare, J. and Seljak, J. (2013). Vodenje ljudi v upravi: povezanost osebnostnega potenciala za vodenje z uspešnostjo vodenja. Ljubljana: Fakulteta za upravo.

Tomaževič, N. (2019). Social Responsibility and Consensus Orientation in Public Governance: a Content Analysis. Central European Public Administration Review, 17(2), pp. 189-204.

Tomescu, M. and Popescu, M. A. (2013). Building Ethical Capital: Perceptions of Ethical Climate in the Public Sector. Public Administration Review, 73(2), pp. 201-206. 
Toonen, T. A. J. (2005). Administrative Reform: Analytics. In Peters, B. G. and Pierre J. (eds.) Handbook of Public Administration, pp. 467-477.

Wilensky, H. (1964). The professionalisation of everyone? American Journal of Sociology, 70(2), pp. 137-158. 